Мср Јелена Јевтић*

докторанд

Универзитет у Београду

Филолошки факултет
004.738.5:316.624

https://doi.org/10.18485/melissa.2018.17.1.ch16

Прегледни рад

Примљен: 23.08.2018

Прихваћен: 11.09.2018.

\title{
ПУТ СВИЛЕ НА ДАРКНЕТУ
}

\section{Сажетак}

Назив првог веб-сајта за илегалну трговину дрогама био је „Пут свиле“. Сајт је основан у фебруару 2011. године и постављен у дубине Даркнета, кутка у децентрализованој мрежи Дарквеба, који није индексиран од стране претраживача веба и коме је могуће приступити само уз нарочити софтвер, конфигурацију или одобрење.

Временом сајт је проширио делатност на друге гране илегалне трговине, омогућио прање новца и друге илегалне операције криптовалутама, а био је и кутак за хакерску виртуелну библиотеку и форум. Овако је кроз метафоричан назив Пут свиле у сајбер-простору наново реализована идеја о размени информација и трговини у информатичко доба, чије ће размере и утицај имати значајне последице за савремену цивилизацију и политичку и економску будућност човечанства.

Млади оснивач сајта Рос Улбрихт, идеалиста, физичар и инжињер, претходно истраживач, напушта научну каријеру како би се опробао у стартапима у Силицијумској долини, али се опредељује за оснивање сајта са идејом да користећи теорију економије омогући човечанству укидање принуде и агресије.

Кључне речи: Пут свиле, интернет, Дарквеб, Дипвеб, Даркнет, Дипнет, Рос Улбрихт, криптовалута, биткоин.

Иза идеје оснивача сајта о слободној и анонимној трговини стоји политичка идеја либертаријанизма, чијој су реализацији интернет и употреба криптовалуте отворили несагледиве видике. Крипто-анархисти залажу се за слободан проток новца на интернету и плаћање без откривања идентитета, што им омогућује не

\footnotetext{
* Филолошки факултет, Студентски трг 3, 11000 Београд jelena.jevtich@gmail.com

1 Silk Road.
} 
само заштиту приватности него и политичку и економску слободу. у вези са либертаријанизмом на интернету јесу и појмови агоризма и контраекономије ${ }^{1}$, односно стварање слободног сајбер тржишта за реализацију трговине која је иначе забрањена или регулисана законима појединачних држава.

„Даркнет“ и „Дарквеб“ појмови су који привлаче широку публику и популарна су тема у масовним медијима. Готово да нема интернет портала са вестима који о њима није писао. Такође, бројни садржаји на „Јутубу“ за младе и љубитеље теорија завере посвећени су управо овим скривеним областима интернета. Књиге из области популарне литературе које обрађују ову тематику, а које не припадају области фикције бележе високе тираже, а самим тим и велико интересовање широке јавности. ${ }^{2}$

Напоредо са популарном продукцијом за широке масе, интригираност овом темом заокупља и стручну јавност. Тако, популарну продукцију посвећену мистеријама „Даркнета“ прати и обимна научна продукција посвећена темама које се баве тајнама интернета. Веб сајт „Пут свиле“, као и друга илегална тржишта забрањеним артиклима на интернету предмет су истраживања истраживача из области информатике и стручњака за безбедност, али и социолога, демографа, криминолога, антрополога, економиста и конкретније економских антрополога.

\section{Терминолошка разлика: „Дипвеб“ и „Даркнет“}

у употреби термина „Дипбев“ и „Даркнет“" неретко влада конфузија, а често се користе и као синоними. Разлог овоме јесте у еволуцији интернета и феномена који се њима означавају. Па ипак, битно је нагласити разлику и разграничити и објаснити домене које

1 Идеје Семјуела Едварда Конкина III, који је заговарао слободно тржиште и економију засновану на размени између појединаца мимо регулативе било ког естаблишмента.

2 Demant, J., Munksgaard, R. \& Houborg, E. Trends Organ Crim (2018) 21: 42.

3 Надаље нећемо наводити ова два термина под наводницима. Такође, може се даље дискутовати и остављамо читаоцу ових редова да сам донесе процену о правописном решењу за које смо се определили. Сматрамо да је исправно ове појмове наводити и малим почетним словом, исто као и интернет: даркнет, дипвеб. 
означавају, будући да постоји забуна. ${ }^{4}$

Неки радови настоје објаснити однос између садржаја на површинском нету, Дипнету и Дипвебу помоћу просторне метафоре океана. Премда ово поређење јесте смислено, често уноси забуну око разумевања разлике и односа између Дипвеба и Даркнета.

Дипвеб је добио име по томе што се налази испод површине веба, односно мреже. ${ }^{5}$ Речено једноставним језиком, видљиви веб је колекција Интернет извора којима је могуће приступити кроз ХТТП протокол и друге компатибилне протоколе. Ове странице индексиране су у претраживачима. Индексирање најчешће јесте спроведено помоћу веб спајдера, кролера, који попут Гугловог алгоритма за рангирање страница, идентификују и организују ХТМЛ хиперлинкове према значају, фреквенцији посећености или вредности.

Дипвеб такође садржи ХТТП изворе, али хиперлинкове није могуће индексирати помоћу претраживача из следећих разлога:

- Подаци ка којима воде линкови налазе се иза пејвола или сајта који је на неки други начин заштићен и приступ је ограничен,

- Подаци нису читљиви или су недовољно значајни према критеријумима рангирања претраживача да би били индексирани,

- Део су изоловане приватне мреже, уграђени у базу података или репозиториј са подацима које је једино могуће претражити кроз упит или мрежни програм. ${ }^{6}$

Примери података који се налазе на Дипвебу, а нису доступни помоћу претраживача јесу: странице „Фејсбук“ профила које нису јавне него доступне само пријатељима на овој друштвеној мрежи, информације у државним и судским базама, базе података у библиотечким каталозима, архивска досијеа, приватни и интерни подаци организација.

Није сваки садржај на Дипвебу скривен. Неке странице јесу заштићене, али уз транспарентан услов приступа, а друге једноставно

4 Berghel, Hal., Which Is More Dangeorus - The Dark Web or the Deep State?, Computer 50, Issue 7 (2017) 86-91.

5 Е. Бишевац, М.Сарачевић, Е. Корићанин, М. Делић, Увид у Даркнет и његов начин функционисања, Правне теме, година 4, број 7, Нови Пазар 2013, 267-274.

6 Berghel, Hal., Which Is More Dangeorus - The Dark Web or the Deep State?, Computer 50, Issue 7 (2017) 86-91. 
нису захваћене претрагом претраживача. Ово важи нарочито за сајтове који се састоје из више страница, од којих су неке дубље постављене од других. ${ }^{7}$

Погрешно је тврдити да је Даркнет само подскуп информација са Дипвеба. Ова два ентитета различита су по дизајну и сврси и само случајно користе исте интернет протоколе. Невидљивост Дипвеба резултат је његове недоступности претраживачима. Премда су његови извори скривени, није их немогуће лоцирати. Даркнет, насупрот томе, дизајниран је да буде скривен од претраживача и уобичајених корисника интернета и доступан је искључиво путем претраживача који штите приватност корисника, као што су Тор и I2P (geti2p.net).

Заједничка одлика сервиса на Дарквебу јесте да њихова локација или садржај страница, или оба, јесу тако дизајнирани да буду скривени од претраживача који претражују површински веб, као што су Фајерфокс и Гугл хром. Ови сервиси су означени од стране .онион ${ }^{8}$ домена, чије је име изведено од низа слојева енкрипције између сваког нода, тј. тачке контакта у мрежи. Слојевита енкрипција омогућава само крајњим тачкама да читају поруку, а средњи/прелазни нодови читају само околне ИП адресе, али не и адресу извора или крајње дестинације. Слање порука овим путем може се тумачити као ланчани пренос у коме су само неке од суседних карика видљиве.

Основни мотив иза Даркнета јесте потпуна анонимизација размене информација на интернету: пошиљаоца, примаоца и сервера, као и потпуна енкрипција порука. Да би се ово постигло Тор пројекат је обезбедио мрежну инфрструктуру од око 10000 независних рута ${ }^{9}$ помоћу којих се формира енкриптовани коло кроз који се саобраћај пропушта. Ово такође помућује насумичне путање конекција, као што и поруке чува шифрованим у тунелу. Међународни корисници онион протокола јесу „Викиликс“, „Бајлдликс“, „Глобалликс“ и „Сикјур дроп“, од којих сваки обезбеђује анонимност изворима и дисидентима, сајтови друштвених мрежа попут „Фејсбука“, или сајтови активиста „Рајзап“, као и анонимни чет сервис „Рикошет“. Овако се обезбеђује анонимност корисника и избегава пресретање информација. Дар-

\footnotetext{
7 Bradbury, D., Unveiling the Dark Web, Network Security 2014, Issue 4 (2014) 14-17.

8 .onion

9 https://www.torproject.org/
} 
кнет обезбеђује корисницима висок степен безбедности, а негативну пажњу на на њему доступне сервисе привукли су они корисници који су га почели користити за заташкавање илегалних активности. ${ }^{10}$

Ови сервиси привлачни су криминалцима јер им пружају могућност да прекршаје чине под окриљем анонимности, подједнако као и јавна места на којима је гужва и која нису довољно обезбеђена. Према томе, професор Хал Бергел ${ }^{11}$ закључује да је природно очекивати на овим сервисима понашање које није друштвено прихватљиво. Илегално и антисоцијално понашање укључује технологију као средство уколико криминалци процене да им може бити од користи. Поступак одабира технологије је опортунистички и не пружа никакве релевантне премисе да би се доносили закључци о самој технологији.

Превише се у јавности инсистира на вези између криминала и Даркнета. Тако се у први план истичу снаф филм², дечија порнографија, нелегална продаја дрога, тероризмом, наручивање убистава и слични злочини, премда је ово користан сервис и за све борце за транспарентност информација, и активисте за које је такође битна анонимност на нивоу преноса информација. Такође је драгоцен корисницима у земљама са цензуром интернета. Идеја је и била да се онима који би могли бити прогањани због борбе за слободу говора и информација омогући заштита у анонимности. Професор Бергер примећује да се и телефон такође може довести у везу са криминалом, али то не значи да је његова употреба неоправдана и некорисна. ${ }^{13}$ Ови анонимни сервиси немају за примарну сврху обману и злоупотребу.

\section{Технологија илегалних базара}

Илегални онлајн базари опстају захваљујући могућности да се на њима обавља потпуно анонимна трговина. Анонимност корисни-

10 Berghel, Hal., Which Is More Dangeorus - The Dark Web or the Deep State?, Computer 50, Issue 7 (2017) 86-91.

11 Исто.

12 Snuff movie - жанр филма, односно видео-снимак направљен за комерцијалне сврхе на коме је забележено реално убиство.

13 Berghel, Hal., Which Is More Dangeorus - The Dark Web or the Deep State?, Computer 50, Issue 7 (2017) 86-91. 
ка гарантују следеће технологије: Тор претраживач, биткоин и ПГП ${ }^{14}$ енкрипција. ${ }^{15}$

Тор је бесплатан софтвер и товорена мрежа за анонимно претраживање. ${ }^{16}$ Овај претраживач ослања се на концепт познатији као лук рутинг (onion rooting). ${ }^{17}$ Концепт мреже која је конфигурисана попут главице лука први пут креирала је истраживачка лабораторија при морнарици Сједињених Америчких Држава 2002. године. Приликом приступања Интернету преко уобичајених претраживача рачунар директно приступа серверу који хостује веб сајт који се посећује. ${ }^{18}$ Приликом коришћења лук мреже ова веза се прекида и подаци одскачу насумично од једног до другог посредника (машина укључених у мрежу широм света) да би стигли до коначне дестинације. Саобраћај на мрежи се региструје, али је немогуће утврдити идентитет рачунара учесника: интернет провајдер нема увид у то који се сајтови посећују, а посећени сајтови немају информацју о физичкој локацији рачунара са кога им је приступљено. ${ }^{19}$

ПГП енкрипција је протокол за шифровање и дешифровање података. Овај криптосистем за заштиту података који путују различитим мрежним токовима кроз компресију и енкрипцију података, као и енкрипцију кључа сесије омогућује да поруку може да прочита само онај коме је послата, тј. намењена, захваљујући јавном кључу на реципијентовој страни комуникационог канала. ${ }^{20}$

Биткоин се разликује од традиционалних валута по три критеријума:

- Није подржан нити од једне владе и нема централног издавача. Да би одржао конзистентност ослања се на П2П21 мрежу.

- За разлику од традиционалних валута какве су кинески јуан, амерички долар или евро, које су правно регулисане, вред-

14 ПгП, тј. енглески PGP скраћено је од Pretty Good Privacy.

15 Demant, J., Munksgaard, R. \& Houborg, E. Trends Organ Crim (2018) 21: 42.

16 https://www.torproject.org/

Bradbury, D., Unveiling the Dark Web, Network Security 2014, Issue 4 (2014) 14-17.

18 Е. Бишевац, М.Сарачевић, Е. Корићанин, М. Делић, Увид у Даркнет и његов начин функционисања, Правне теме, година 4, број 7, Нови Пазар 2013, 267-274.

19 Bradbury, D., Unveiling the Dark Web, Network Security 2014, Issue 4 (2014) 14-17.

20 Demant, J., Munksgaard, R. \& Houborg, E. Trends Organ Crim (2018) 21: 42.

21 Р2P тj. peer to peer network јесте мрежа у којој су пошиљалац поруке и прималац у комуникацији без трећег арбитра. 
ност биткоина одређена је законом понуде и потражње. Што је више учесника у трговини који као валуту користе биткоин, то више и његова вредност расте.

- Будући да се биткоини размењују електронски кроз П2П мрежу и нису под утицајем регулативе банака или било које треће стране, мање су и подложни економским и политичким утицајима на које су осетљиве друге валуте.

Биткоини ипак имају вредност, као и све друге валуте, и она се може употребити за куповину робе. Најпре су се све трансакције биткоина вршиле онлајн, али је све више трговина и пружаоца услуга ${ }^{22}$ који као валуту прихватају биткоин.

Антрополошки економисти истичу то да биткоин није утемељен ни у једном централизованом ауторитету. Какав је то екоситем дигиталног новца ${ }^{23}$ Инфраструктура екосистема дигиталног новца заснована је на алгоритмима и технологији која омогућује корисницима да чувају и преносе информационе честице биткоина са једног места на друго у дигиталној мрежи. Биткоини јесу вирална валута. Не постоји њихов физички, па ни дигитални еквивалент. Они су обухваћени поруком којом се реализује трансакција, која се потом потврђује на јавно читљивој плочи. ${ }^{24}$ Када се критеријуми дигиталне семиозе испуне, биткоин постоји као знак који се региструје у виду извршене трансакције.

Власници биткоина користе кључеве који им омогућују да откључају информације у вези са биткоинима и обаве трансфер. Ови кључеви ускладиштени су у дигиталним новчаницима на рачунаима власника. Сам новчаник не садржи биткоине. У њему се само налазе кључеви. Свако може да отпочне са рударењем биткоина уколико преузме отворени код биткоин протокола. Рударење је термин који се користи како би се описао процес решавања математичких задатака помоћу процесора на рачунару на коме се изводи ова операција. Власник рачунара притом не решава задатке, већ се цео процес обавља на

22 Најразличитије трансакције могу се обавити коришћењем биткоина. Примају их: кафетерије, прехрамбени ланац Whole Foods, сервиси за изнајмљивање аутомобила, могуће је донирати у биткоинима, итд.

23 Питање које поставља Асиф Агфа у својој антроплошкој студији. Agha, A., Money Talk and Conduct from Cowries to Bitcoin, Signs and Society 5, no. 2 (Fall 2017): 293-355. 
рачунару. У просеку се на мрежи сваких десет минута реши по један од ових задатака и на тај начин неко изрудари један биткоин. Алгоритми све ово обављају на транспарентан начин и нема централног ауторитета који надгледа и регулише производњу ове валуте.

Овај систем плаћања иако се користи свугде у свету и даље је нов и стран многима. Такође је и недовољно разумљив. А постоји и бојазан да ће сваког тренутка пропасти. Многи људи никада нису за њега ни чули, док га други користе редовно. А такође има и оних који га користе за илегалне активности.

Легалан статус биткоина и даље је у сивој зони. Иако га је могуће конвертовати у доларе или евре, многе државе га не признају као прави новац. Ово је и био један од главних аргумената које је Улбрихт употребио на суду када се бранио од оптужби за прање новца, будући да трансакције обављене на „Силк роуду“ по овој логици нису биле финансијске природе. ${ }^{25}$

Трансакција биткоина обавља се између два субјекта. Један од њих преузима софтвер и добија јединствену адресу која изгледа овако: „1efkl3SHAnnprsvdoQmQwwGnpXGTrbG3m5DY“. Ова јединствена идентификација се користи као потпис приликом трансакције. То је једина идентификација на мрежи. Ова адреса налази се у дигиталном новчанику корисника који је њен власник. У тренутку регистрације корисник не поседује биткоине. Потребно је да прими уплату од власника који поседује биткоине. Када прими прву пошиљку биткоина, трансакција се региструје као јавна и сви могу да је виде. Најпре је непотврђена, а када је рудар биткоина укључи у блок трансакција, који се догађа у просеку на сваких десет минута, она се региструје на блокчејну као потврђена. Биткоин, заједно са власником, постоји сада као друштвена чињеница. И може се даље трошити.

Не постоји, дакле, физички објекат или дигитални фајл који је означен као биткоин. Уместо тога само су видљиве трансакције на огромној јавној табли која се зове блокчејн.

Блокчејн поседује бројне копије на бројним серверима и не може се лажирати. Такође је осигуран јавним криптографским методама.

Већини корисника није сасвим јасно како биткоин функционише, али је ипак неопходно уложити одређено време да би се развио

25 Kethineni, S., Cao, Y. \& Dodge, C. Am J Crim Just (2018) 43: 141. 
одређени степен дигиталне писмености и разумела природа виралних трансакција.

Време је неопходно уложити и у чекање испроруке, тако да је главнина трговине која се спроводи на криптотржиштима у домену Б2Б трговине 26 . Купци су заправо препродавци који на овим илегалним криптотржиштима набаљају веће количине недозвољених средстава ради даље дистрибуције.

\section{Понашање и искуство корисника 27}

Трговина на „Силк роуду“ описана је од стране корисника сајта као софистицирана. Учесници у трговини себе су описали као интелигентне и одговорне купце. ${ }^{28}$ Репутација на самом сајту, која је јавна, јесте оно захваљујући чему су продавци опстајали у бизнису. Продавац који жели да се добро рангира међу конкуренцијом неопходно је да се потруди око тога да од сваког купца добије позитивне рецензије. Ово га препоручује за даљу сарадњу.

Што се тиче криминалног понашања, постоји интересантна теорија аутора Џејашанкара, а то је теорија транспоновања у простору. ${ }^{29}$

1. Појединци који потискују потребу за криминалним понашањем неће је потискивати у сајберспејсу јер им окриље анонимности пружа могућност да испоље своје склоности без обзира на статус у реалном животу,

2. Флексибилност идентитета, дисоцијативна анонимност и недостатак одвраћања јесу олакшавајући фактори који мотивишу преступнике да почине злочин,

3. Криминалци из реалног света уносе криминално понашање у сајберспејс и обрнуто

26 Business to bussines, као модел трговине између два бизниса, у овом случају то су произвођач и препродавац.

27 Студија корисничког искуства (user experience) спровели су Hout, M.C.V. \& Bingham T., International Journal Of Drug Policy (2014) 25: 183.

28 Исто.

29 Space Transition Theory, као кримилолошка теорија која објашњава понашање преступника када из физичког простора своје активности преселе у сајбер простор. 
4. Сајберкриминалцима је олакшано утицање захваљујући повременом статусу подхвата и динамичној спациотемпоралној природи сајберспејса

5. Криминалци се удружују у сајберспејсу да би починили злочине у физичком простору

6. Већа ероватноћа је да људи у затвореним друштвима почине злочин

7. Конфликт норми и вредности између физичког простора и сајберспејса води ка сајберкриминала

Закључак професора са Прери Вју универзитета је да је флексибилност идентитета примарни фактор који привлачи криминалце на интернет, и конкретније на сајт „Силк роуд“. Више од 80\% криминалаца користе и два и више идентитета. ${ }^{30}$ Криминалци су захваљујући овој флексибилности, иако у честом контакту, безбедно скривени и једни од других.

Изузетно занимљив детаљ у једном од истраживања које смо прочитали јесте то да су се истраживачи захвалили администраторима сајта „Силк роуд“, који су били свесни њиховог присуства на сајту, али их нису ометали у истраживању. ${ }^{31}$

Када је сајт „Силк роуд“ затворен, тржишну потребу за сајтовима овакве врсте употпунили су сајтови „Силк роуд 2.0“, „Силк роуд 3.0“ и „Агора“. Принцип по коме сви они функционишу је сличан.

Популарност криптотржишта расте, што је испраћено и варијацијама у демографским трендовима. С тим у вези сва до сада спроведена истраживања релативно брзо застаревају и наново настаје потреба за даљим демографским, криминолошким и економским испитивањима.

30 Рос Улбрихт, власник Силк роуда је, примера ради, корстио идентитете као што су Dread Pirate Roberts, DPR и Silk Road, док је агент ФБИ-ја који га је контактирао користио псеудониме: NOB, French Maid и Carla Sophia.

31 Hout, M.C.V. \& Bingham T., International Journal Of Drug Policy (2014) 25: 183. 


\section{ЛИТЕРАТУРА}

Agha, A., Money Talk and Conduct from Cowries to Bitcoin, Signs and Society 5, no. 2 (Fall 2017): 293-355.

https://doi.org/10.1086/693775

Berghel, Hal., Which Is More Dangeorus - The Dark Web or the Deep State?, Computer 50, Issue 7 (2017) 86-91.

http://doi/10.1109/MC.2017.215

Bradbury, D., Unveiling the Dark Web, Network Security 2014, Issue 4 (2014) 14-17.

https://doi.org/10.1016/S1353-4858(14)70042-X

Demant, J., Munksgaard, R. \& Houborg, E. Trends Organ Crim (2018) 21: 42.

https://doi.org/10.1007/s12117-016-9281-4

Е. Бишевац, М.Сарачевић, Е. Корићанин, М. Делић, Увид у Даркнет и његов начин функционисања, Правне теме, година 4, број 7, Нови Пазар 2013, 267-274.

Hout, M.C.V. \& Bingham T., International Journal Of Drug Policy (2014) 25: 183.

https://doi.org/10.1016/j.drugpo.2013.10.009

https://www.torproject.org/

Kethineni, S., Cao, Y. \& Dodge, C. Am J Crim Just (2018) 43: 141.

https://doi.org/10.1007/s12103-017-9394-6

Laura, L. \& Me, G. Soft Comput (2017) 21: 1245.

https://doi.org/10.1007/s00500-015-1857-4

\section{Jelena Jevtić}

\section{SILK ROAD ON THE DARKNET}

\section{Summary}

The name of the first website for illegal drug trafficking was Silk Road. The site was established in February 2011 andinstalled in the Darknet area, a corner in decentralized Dark web networks that is not indexed in a browser and which can be accessed only through a special software, configurations or approval.

Over time, the site expanded its activities to other branches of illegal trade, provided money laundering and other illegal operations crypto currencies, and was also the corner for a hacker virtual library and forum. Thus, through the metaphorical name 
Silk Road in cyberspace, the idea of i nformation exchange and trade in the information age has been remade. Its impact will have significant consequences for the contemporary civilization and the political and economic future of mankind.

The young founder of the site, Ross Ulbricht, an idealist, physicist and engineer, previously a researcher, is leaving a scientific career to try out the startups, but opts for creating a site with the idea that using economics theory will allow mankind to cease and abolish coercion and aggression.

Behind the idea of $t$ he founder of the site about free and anonymous trade is the political idea of I ibertarianism, whose realization of the Internet and the use of crypto currency opened unimaginable aspects. Crypto-anarchists advocate the

free flow of money on the Internet and payment without revealing identity, which enables them not only to protect privacy but also to have political and economic freedom. Regarding libertarianism on the Internet, there are also concepts of aggression and counter-economy, that is, the creation of a free cyber market for the realization of trade, which is otherwise prohibited or contested by the laws of individual states.

Key words: Silk Road, Darknet, Dark web, internet, free trade, free market, Ross Ulbricht, cryptocurrency, bitcoin, digital gold. 